\title{
Strategi Negosiasi Masyarakat Muslim Pedesaan Atas Tradisi Perkawinan Lusan (Studi Kasus di Desa Duri Kecamatan Slahung Kabupaten Ponorogo)
}

\author{
Arifin Musthofa, Arik Dwijayanto \\ Institut Agama Islam Sunan Giri (INSURI) Ponorogo \\ arifalmustofa@gmail.com,arikdj99@gmail.com
}

\begin{abstract}
Abstrak
Adat larangan nikah lusan menjadi dinamika tersendiri, bagi generasi saat ini khususnya. Namun larangan adat nikah lusan tersebut masih dapat dilaksanakan dengan beberapa upaya dan alternatif yang sesuai dengan adat yang berlaku. Hal tersebut yang menjadi latar belakang penelitian ini. Tujuan penelitian ini untuk mengetahui rasionalisasi/alasan masyatakar Desa Duri dalam menjalankan tradisi perkawinan lusan,untuk mendeskripsikan praktik nikah lusan di Desa Duri Kecamatan Slahung Kabupaten Ponorogo, untuk menganalisis strategi dalam melangsungkan nikah lusan tersebut, dan dapat menjalankan pernikahan tersebut tanpa ada halangan apapun. Teknik pengumpulan data pada penelitian ini dengan wawancara, observasi, dokumentasi. Teknik analisis data pada penelitian ini dengan mengunakan reduksi data, penyajian data, penarikan kesimpulan/verifikasi. Hasil penelitian ini menunjukkan bahwa larangan nikah lusan di Desa Duri masih dipegang teguh oleh masyarakat. Akan tetapi praktik nikah lusan dilaksanakan dengan adanya ruwatan. Sebagai sebuah strategi negosiasi tentang adanya nikah lusan masyarakat menyelenggarakan ruwatan nemu anak, tidak adanya wali perempuan, tidak ada istilah besanan.
\end{abstract}

Kata kunci: Strategi Negosiasi, Masyarakat Muslim Pedesaan, Tradisi, Perkawinan.

\begin{abstract}
The custom of prohibiting marriage after marriage has become its own dynamic, especially for the current generation. However, the ban on the customary marriage after marriage can still be implemented with several efforts and alternatives that are in accordance with applicable customs. This is the background of this research. The purpose of this study is to find out the rationalization/reasons of the people of Duri Village in carrying out the tradition of marriage after marriage, to describe the practice of marriage after marriage in Duri Village, Slahung District, Ponorogo Regency, to analyze the strategy in carrying out the marriage after marriage, and to be able to carry out the marriage without any obstacles. Data collection techniques in this study by interview, observation, documentation. Data analysis techniques in this study using data reduction, data presentation, drawing conclusions / verification. The results of this study indicate that the prohibition of late marriage in Duri Village is still firmly held by the community. However, the practice of marriage after marriage is carried out in the presence of ruwatan. As a negotiation strategy regarding the existence of marriages, the community held a ruwatan to find children, there was no female guardian, there was no term besanan.
\end{abstract}

Keywords: Negotiation Strategy, Rural Muslim Community, Tradition, Marriage. 


\section{A. Pendahuluan}

Membahas tentang kebudayaan atau adat yang telah berlaku di suatu tempat sering kali terjadi konflik atau perbedaan antara syariat islam dengan adat istiadat yang telah berlaku pada suatu daerah, terlebih hal itu telah menjadi tradisi yang sudah mengakar serta telah menjadi sebuah hukum adat. Adat istiadat yang diyakini dan telah menjadi hukum akan lebih kuat karena pelanggaran terhadapnya akan menemui suatu sanksi atau akibat dengan sesuai peraturan yang berlaku dan diyakini dalam suatu komunitas. Seperti di Ponorogo, sebagai kabupaten yang memiliki nilai religisitas dan kebudayaan yang kuat. Dalam beberapa ketentuan kehidupan terdapat beberapa kepercayaan adat jawa yang sangat diyakini. Dalam hal ini adalah adat tentang pernikahan. Terdapat berbagai ketentuan tentang adanya pernikahan. Misal pemilihan jodoh yang harus disesuaikan dengan tanggal lahir, hari lahir dan lain sebagainya. Ketentuan lain dalam pernikahan yang dipercaya masyarakat adalah tidak bolehnya nikah lusan. Yaitu sebuah pernikahan yang di lakukan anak nomor satu dan anak yang ketiga atau sebaliknya sehingga bertemunya satu dan tiga menjadi ganjil (Solikin: 2010).

Berangkat dari beberapa penelitian awal bahwa, hampir semua daerah di kabupaten Ponorogo masih meyakini kepercayaan larangan nikah lusan. Seperti halnya di Desa Sawoo, Desa Siman, dan Jambon dan daerah lainnya. Secara umum, masyarakat masih sangat meyakini bahwa larangan nikah lusan masih benar adanya, sehingga masih dipatuhi sampai dengan saat ini. Keyakinan terhadap adat larangan nikah lusan dijalankan dengan dasar mengikuti petuah dan pesan para leluhur nenek moyang. Dalam kepercayaan terhadap larangan pernikahan lusan masyarakat meyakini bahwa apabila adat pelarangan nikah lusan tetap dilaksanakan akan terjadi berbagai musibah. Berbagai musibah tersebut, sebagaimana diyakini adalah seperti halnya sakit tidak akan ada sembuhnya, ada yang orang tua pasangan nikah lusan berakibat cerai.

Berbagai dampak tersebutlah yang menjadikan sebagian besar masyarakat di Ponorogo khususnya masih memegang teguh aturan adat pernikahan. Namun ada sebagian masyarakat yang meyakini bahwa larangan pernikahan lusan adalah mitos semata. Kelompok masyarakat yang beranggapan bahwa berbagai larangan adat dalam pernikahan di Jawa sebagai mitos meyakini bahwa setiap musibah akibat sudah menjadi takdir Allah SWT.

Dalam penelitian ini sengaja peneliti mengambil lokasi di daerah Ponorogo dikarenakan terdapat beberapa perbedaan syarat pernikahan lusan adapun di Desa Siman Ponorogo, Banjar Panjang dan Giripurno mereka hanya menggunakan syarat tidak adanya sanggan yaitu barang bawaan berupa beras, gula, dan pada pernikahan umumnya. Sedangkan di Kabupaten Ponorogo terdapat beberapa persyaratan untuk melakukan nikah lusan selain tidak adanya sanggan pasangan lusan harus di kebokne yaitu pengantin di bebaskan sendiri untuk melangsungkan pernikahan mereka tanpa ada campur tangan siapapun, ngeger yaitu pengantin harus di asingkan terlebih dahulu hingga ada orang yang menemukan hingga di kebalikan kepada orang tuanya, adanya hari baik dan adanya ruwatan dari bujangga.

Di desa Duri Kecamatan Slahung, adat Jawa dalam berbagai hal masih sangat dipegang teguh sebagai keyakinan dari nenek moyang. Termasuk dalam hal perjodohan/pernikahan. Dalam hal larangan nikah lusan, orang-orang terdahulu sangat menjaga adat tersebut dan tidak berani untuk melanggarnya . Masyarakat Desa Duri kebanyakan masih sangat memegang teguh hukum adat yang berlaku, namun orang yang telah diperantauan dibolehkan melaksanakan pernikahan tanpa menyesuaikan hukum adat daerahnya, bahkan tidak dengan upacara serangkaian adat Jawa sekalipun.

Dalam tradisi Jawa, kehidupan adalah sesuatu yang sangat penting. Setiap langkah peristiwa dan fase dalam kehidupan manusia ditandai dengan serangkaian upacara dengan menggunakan berbagai simbol hasil kolaborasi tradisi budaya Jawa dan Islam. Apalagi 
semenjak masyarakat Jawa secara umum telah memeluk agama Islam yang penyebarannya dilakukan dengan proses akulturasi maupun asimilasi dengan budaya lokal oleh para walisongo. Apa yang dilakukan oleh Walisongo tersebut berdampak pada tradisi dan kebiasaan mereka yang berkaitan erat antara Islam dan tradisi (adat) Jawa (Janah : 2013).

Relasi antara tradisi (adat) Jawa sebagai sebuah sistem sosial telah memberikan fenomena sosial yang menarik untuk dicermati. Sebagai contoh upacara-upacara lingkaran hidup masyarakat jawa yaitu prosesi pernikahan dan dilanjutkan dengan serangkaian upacara kelahiran anak dan juga upacara kematian. Upacara yang diselenggarakannya minimal telah memberikan implikasi adanya proses akulturasi budaya Jawa dan Islam yang berjalan dengan harmonis(Poesponoto : 1983).

Tema tentang proses interaksi antara tradisi pernikahan dan nilai Islam menjadi pro dan kontra menurut ajaran Islam dan tentu menjadi masalah bagi masyarakat Muslim Indonesia yang heterogen. Bahkan dalam realitasnya ditemukan banyak varian. Adanya disparitas antara konsep ideal dengan realitas empirik inilah oleh peneliti dianggap sebagai problem mendasar dari penelitian ini. Disamping itu juga faktor lain berupa perbedaan tradisi serta tatacara yang harus diikuti selama tradisi tersebut berlangsung yang dalam pelaksanaannya tidak terlepas dari penggunaan simbol dan lambang baik berupa benda, materi, fisik, isyarat, dan kejadian maupun makna terdalam dari seluruh rangkaian tradisi yang ternyata juga masih menjadi perdebatan tersendiri bagi masyarakat.

Terlepas dari kontroversi tersebut, realitas menunjukkan bahwa ritual dan tradisi tersebut selalu dilakukan oleh kalangan muslim tradisional pada ummnya, bukan hanya di Jawa, namun menyebar ke pelosok Nusantara terbawa oleh orang Jawa yang kemudian bermukim di berbagai pulau di Nusantara. Dengan demikian, walaupun bisa dikatakan bahwa hal itu termasuk dalam kawasan religius atau ranah agama, namun perlu disadari bahwa aspek yang dominan adalah budaya suatu masyarakat. Oleh karena itu, jika hal tersebut kemudian dinyatakan sebagai ritual keagamaan, seharusnya dipandang sebagai budaya keagamaan, bukan sebagai ajaran inti agama itu sendiri. Sehingga pun dilaksanakan, maka tidak mengapa, justru menambah syi'ar keagamaan. Sebaliknya, jika kemudian oleh sebagian orang (muslim) hal tersebut tidak dilaksanakan, juga tidak mengapa, karena bukan sebagai bagian normatif dari agama, yang penting bahwa substansi agama dalam pelaksanaan ritual kelahiran, pernikahan, dan kematian seorang muslim tetap dilaksanakan dan dijaga.

Sikap yang arif atau bijaksana diperlukan dalam menyikapi hal itu. Agama dan keberagamaan tidak akan hidup secara sejuk dalam masyarakat, jika tidak mengadopsi berbagai budaya yang baik (al-sunnah al-tsaqafiyyah) bagi pengembangannya. Oleh karena itu perlu dipertimbangkan, jika unsur-unsur dalam suatu budaya yakni aspek lokalitas akan dicabut secara sistematis dan menyeluruh dari agama, maka yang terjadi adalah keburukan dalam bentuk pertentangan antagonis antar kelompok masyarakat.

Memahami tentang Perkawinan, secara sadar pernikahan/perkawinan harus dapat dipertahankan oleh kedua belah pihak agar dapat mencapai tujuan dari perkawinan tersebut, sehingga dengan demikian perlunya ada kesiapan kesiapan mental, jiwa fisik untuk bekal kedepannya hidup bersama masyarakat yang penuh warna-warni karakter perilaku dalam kehidupan masyarakat. Sehingga harus bisa meletakkan posisi yang harus bagaimana dengan cara bagaimana bergaul dan berbaur dengan masyarakat yang telah nyata esok. Hal ini dapat di ukur dari segi taraf kedewasaanya sehingga siap untuk mengarungi bahtera kehidupan suami istri yang cukup dewasa akan mampu memahami perasaan. Kedewasaaan dalam bidang fisik biologis sosial maupun ekonomi,emosi dan tanggung jawab, akan menyebabkan keluarga yang terbentuk dalam keadaan yang demikian mempunyai saham besar dan meyakinkan untuk meraih taraf kebahagian dan kesejahteraan hidup dalam rumah tangga hingga di masyarakat 
(Basri : 2004).

Dalam kehidupan masyarakat jawa, khususnya di Ponorogo, maka setiap manusia yang akan melangsungkan pernikahan seyogyanya harus mampu memposisikan diri dengan budaya yang ada. Sehingga harmonisasi dalam pernikahan bisa didapatkan dengan baik dan benar. Ketentuan tentang adat, dalam masyarakat jawa menjadi sebuah hukum ang mengikat dan harus dijalankan setiap masyarakat. Dari hasil penjajakan di Desa Duri Kecamatan Slahung Kabupaten Ponorogo peneliti mendapatkan informasi bahwa nikah lusan masih menjadi bunga bibir di daerah tersebut walaupun nikah lusan sepenuhnya sangat ditaati. Adat larangan nikah lusan menjadi dinamika tersendiri, bagi generasi saat ini khususnya. Namun larangan adat nikah lusan tersebut masih dapat dilaksanakan dengan beberapa upaya dan alternatif yang sesuai dengan adatyang berlaku.

\section{B. Metode Penelitian}

Jenis penelitian ini merupakan jenis penelitian lapangan (field research) yaitu mengumpulkan data yang dilakukan di lapangan di tempat terjadinya yang akan di teliti. Jenis penelitian ini adalah deskriptif kualitatif yaitu penelitian yang ditujukan untuk mendeskripsikan apa-apa yang berlangsung saat ini. Penelitian kualitatif, memiliki karakteristik bahwa datanya dinyatakan dalam keadaan kewajaran atau sebagaimana adanya (natural setting) dengan tidak merubah dalam bentuk symbol atau bilangan (angka-angka).

Adapun pendekatan yang akan penulis lakukan menggunakan pendekatan kualitatif. Yaitu prosedur penelitian yang menghasilkan data deskriptif berupa kata-kata tertulis dari informasi lapangan atau lisan dari orang-orang dan perilaku yang dapat dialami. Data-data tersebut berupa kata-kata atau gambar srta hasil naskah wawancara, catatan lapangan (observasi) maupun dokumen-dokumen berdasarkan keadaan lapangan.

\section{Hasil Penelitian}

Dalam konteks pernikahan atau penentuan jodoh ada beberapa wewaler atau larangan yang tidak boleh dilakukan oleh masyarakat. Karena jika dilanggar akan terjadi ciloko. Ciloko dalam hal ini bisa terjadi dalam bentuk apapun, yang dianggap sebagai akibat dari dilanggarnya peraturan adat yang berlaku. Dampak-dampak yang terjadi - menurut keyakinan masyarakat - bila seseorang melanggar adat dalam hal perkawinan secara umum mereka para masyarakat Jawa mengatakan dampak bila melanggar adat perkawinan mungkin hidupnya akan sengsara, tidak tenang, rumah tangga selalu ada konflik, dan bisa menjadi perceraian. Akan berdampak juga kepada orang tua kedua mempelai, keluarga, kerabat, bahkan sampai masyarakat setempat. Serta anak turun, musibah, malapetaka, kesengsaraan itu akan sampai ke anaknya yang acuh terhadap urusan orang tuanya. Orang zaman dahulu sangat kuat dalam meyakini akan adanya hal itu, namun ada sebagian orang menganggapnya itu hanya mitos saja.

Memilih calon jodoh pada zaman dulu, terutama adat Jawa dilakukan oleh orang tua. Orang tua akan melakukan seleksi terhadap calon suami ataupun istri bagi anaknya. Seleksi dilakukan atas dasar pertimbangan faktor keluarga dan keturunan, naptu kelahiran, faktor ekonomis norma tradisi, serta persetujuan lainnya. Seorang anak tidak boleh melakukan pilihan sendiri, bahkan tidak jarang calon suami-istri baru berjumpa untuk petama kalinya 
pada saat upacara perkawinan. Pemilihan jodoh dilakukan dengan ketat oleh orang tua dengan menekankan paksaan dan peraturan yang harus ditaati oleh anak. Hal tersebut terjadi karena orang tua merasa mempunyai kekuasaan dalam proses pemilihan jodoh.

Pada suku Jawa, pemilihan jodoh dilakukan atas dasar pertimbangan "bibit, bebet, bobot". Faktor bibit yaitu mempertimbangkan benih asal keturunan, seperti sehat jasmani dan rohaninya, tidak berpenyakitan karena bibit yang baik akan menghasilkan keturunan yang baik. Faktor bebet yaitu memperhatikan asal usul keluarga. Umumnya orang menginginkan calon suami atau istri yang berasal dari keluarga bangsawan atau berketurunan darah biru karena akan mendapatkan penghormatan dan terpandang. Faktor bobot yaitu memperhatikan harkat, martabat,ilmu pengetahuan yang lengkap, memiliki kekayaan, serta kekuasan. Dengan demikian dianggap dapat memberikan kebahagiaan secara materi (Huda : 2016).

Peraturan tradisional dalam adat Jawa tersebut lambat tahun mengalami perubahan seiring dengan pengaruh edukasi dan modernisasi. Anak mempunyi kebebasan untuk menentukan pilihan dan tidak lagi harus menurut pada orang tua mengenai pasangan hidupnya. Orang tua beranggapan bahwa masalah memilih jodoh dan perkawinan tidak hanya pertanggungjawaban orang tua saja akan tetapi juga oleh anak. Dengan demikian anak mempunyai kebebasan untuk memilih pacar atau calon jodohnya.

Dalam beberapa kasus, beberapa larangan dalam pernikahan adat jawa tersebut menjadi masalah tersendiri bagi calon pengantin. Namun, sebagaimana data yang didapatkan penulis bahwa peraturan yang ada tidak sepenuhnya harus kaku dijalankan. Calon pengantin yang sedang menghadapi hukum adat tersebut dapat dicarikan jalan keluar sebagai solusi akan pernikahan tetap bisa berlanjut. Disinilah, strategi negosiasi dalam pernikahan dilakukan. Khususnya pernikahan lusan.

Negosiasi merupakan proses untuk mencapai kesepakatan dengan memperkecil perbedaan serta mengembangkan persamaan guna meraih tujuan bersama yang saling menguntungkan. Dengan demikian, negosiasi secara umum dapat diartikan sebagai proses untuk mengkomunikasi suatu permasalahan dengan mencari jalan tengah yang sama-sama telah disepakati dan dijalankan bersama. Untuk itu, diperlukan komunikasi guna menyelesaikan permasalahan yang terjadi.

Diantara strategi dalam negosiasi nikah lusan di Desa Duri adalah sebagai berikut:

1. Nemu Anak

Neти Anak, merupakan solusi yang lazim digunakan dalam mengatasi nikah lusan di Desa Duri, bahkan Ponorogo pada umumnya. Strategi ini, menurut penuturan salah satu tokoh adat/berjonggo di Desa Duri, dikatakan oleh Mbah Karso bahwa, istilah Nemu Anak yaitu adanya beberapa prosesi sebelum pernikahan dilangsungkan. Orang tua mempelai pria datang ke rumah mempelai putri, dan mengatakan "kulo nemu anak lanang, namine Dimas (seumpama) terus kulo openi dugi sakniki, amergi pun wancine nikah nggeh kulo nikahaken, kaleh lare sing di remeni". (Saya menemukan anak lelaki, namana Dimas (seumpa) dan saya adopsi sampai saat ini, dikarenakan sudah waktunya menikah maka saya nikahkan dengan gadis yang disukai).

Prosesi demikianlah yang dinamakan "Nemu Anak”. Namun kebanyakan masyarakat dahulu yang masih kuat keyakinan terhadap hukum ada maka tidak akan berani untuk 
melanggar atau bahkan sekedar melakukan negosiasi agar pernikan lusan bisa dilaksanan. Sebagaima di pertegas Mbah Karso "jika tidak bisa ya tidak bisa, atau adiknya yang disuruhnikah dulu”.

2. Tidak adanya Besanan

Istilah tidak adanya besanan, yaitu rangkaian prosesi pernikahan dilangsungkan di rumah mempelai salah satu baik itu laki-laki ataupun perempuan, dengan cara seperti itu salah satu cara untuk melangsungkan pernikahan lusan. Karena apabila prosesi acara pernikah itu dilangsungkan di rumah kedua mempelai itu sama saja halnya dengan tidak adanya ritual/ruatan atau jalan keluar untuk melangsungkan pernikahan lusan, dan itu akan menimbulkan hal-hal buruk yang tidak diinginkan kedua mempelai, keluarga, kerabat, bahkan masyarakat setempat.

\section{Ritual Tolak Bala'}

Ritual tolak bala' yaitu doa meminta kepada Allah SWT untuk melancarkan segala prosesi pernikahan yang akan dilakukan oleh pelaku nikah lusan tersebut, biasanya ritual itu dengan diadakannya selametan atau kenduri. Selametan tersebut bertujuan untuk menjauhkan segala mara bahaya, bencana, musibah, yang tidak di inginkan keluarga, masyarakat dan mempelai pengantin. Biasanya acara selametan tersebut dilakukan sebelum acara resepsi pernikahan, baik itu di rumah mempelai laki-laki dan perempuan. Selametan tersebut biasanya melibatkan masyarakat, tokoh agama setempat, tokoh adat, dan kerabat sanak saudara dari mempelai pengantin.

4. Akad Nikah Tidak dilaksanakan di Rumah Mempelai

Beberapa hal yang dilaksanakan untuk menyiasati pernikahan lusan, menurut keyakinan masyarakat, warga Desa Duri yaitu, pelaku pernikahan Lusan (Calon Pengantin Lusan) jika ingin melangsungkan pernikahan maka pengantin laki-laki untuk melangsungkan ijab qobul harus berangkat dari rumah saudara atau tetangga yang rumahnya dekat dengan rumah mempelai laki-laki tersebut dan tidak berangkat dari rumah mempelai laki-laki langsung, karena itu sama saja halnya dengan pernikahan biasa tidak ada strategi untuk menyiasati pernikahan lusan secara langsung. Langkah ini dimaksudkan bahwa mempelai laki-laki diakui menjadi anak orang yang rumahnya di tempati mempelai laki-laki untuk berangkat melakukan ijab qobul.

Strategi negoisasi lain dalam pernikahan lusan, kata seorang tetua/ kyai di Desa Duri, beliau adalah Bapak Slamet, salah satu imam di Masjid Desa Duri. Beliau mengatakan bahwa,dikembalikan pada keyakinan orang yang melakukan, harus mantab, yakin hatinya, kalau tidak bisa ya cari yang lain itu solusinya. Di kembalikan ke nenek moyang kita, jaman dulu, mereka memilih adat atau tradisi seperti itu tentu untuk kebaikan anaknya sampai turun temurun. Dan kata beliau Bapak Slamet, disuruh menikahi orang lain dulu, baru selang beberapa lama diceraikan dan menikahi orang yang di cintainya. Tapi sebuah pernikahan itu adalah ikatan sakral, suci, seumur hidup untuk selamanya, bukan untuk dipermainkan. Di dalam Al Qur'an dan Al Hadist larangan seperti itu tidak ada, di kembalikan ke Allah SWT. Allah SWT telah menggariskan kehidupan kita kelak di dunia maupun di akhirat, sebelum kita di ciptakan. 
Masyarakat telah melaksanakan komunikasi antar pribadi setiap harinya. Mereka bertemu, berbincang dan saling bertukar pikiran melalui komunikasi antar personal. Bahkan sebuah berita dapat menyebar dengan cepat melalui komunikasi atar pribadi yaitu berupa desas- desus warga. Masyarakat telah memahami bagaimana cara berkomunikasi yang baik dan benar. Mereka selalu sadar dengan stratifikasi atau pembagian struktur masyarakat yang ada di desa. Misalnya bagaimana ketika harus berbicara dengan kiai atau sesepuh desa.

Sesuai dengan pengertian di atas tentang komunikasi interpersonal, dalam hal aktivitas menggunakan weton, lusan, dan lain-lain, masyarakat melakukan komunikasi atar pribadi dengan sesepuh yang dianggap mampu dan memahami tentang weton, lusan beserta perhitungannya. Mereka (sesepuh) memberikan informasi atau pesan kepada masyarakat, tentang simbol yang muncul dari perhitungan mereka dan warga menerima pesan tersebut. Sesepuh tidak mengharap sebuah timbal balik dari pesan yang sudah mereka sampaikan, namun warga tetap akan melakukan timbal baik tersebut. Misalnya seperti memberikan ucapan terimakasih dan memberikan kepercayaan terhadap sesepuh untuk menggunakan hasil dari perhitungan tersebut. Dari sini telah terlihat bahwa komunikasi yang telah dilakukan leh masyarakat bukan komunikasi yang bersifat memaksa, meskipun terdapat stratifikasi yang sedikit membedakan antara warga biasa dan masyarakat sesepuh atau priayi. Para sesepuh memberikan kebebasan sepenuhnya kepada warga untuk melakukan sesuai dengan pesan yang mereka sampaikan.

Gambaran di atas dapat dikatakan sebagai proses transaksional karena masyarakat menerima apa yang menjadi gagasan dan pikiran dari sesepuh desa terhadap simbol yang telah dimunculkan dari perhitungan yang mereka lakukan. Kemudian masyarakat melakukan reaksi dari pesan yang disampaikan berupa menerima atau menolak yang sesuai dengan rumusan komunikasi transaksional: Pertama, komunikasi antarpribadi merupakan proses. Kedua, komponen-komponennya saling tergantung (interdependensi) dan pelaku komunikasi bertindak sekaligus bereaksi.

Dalam teori interaksionalisme simbolik ditegaskan bahwa ada dua hal penting yang menandai kehidupan manusia, yaitu interaksi dan simbol. Interaksi itu penting karena ia menunjukkan kehidupan sosial dimana orang saling mengerti, saling menanggapi dan saling berkomunikasi. Lusan sebagai salah satu budaya yang muncul akibat dari interaksi yang terjalin antara nenek moyang kita. Interaksi ini terjadi secara terus-menerus yang kemudian menimbulkan suatu nilai yang disepakati bersama. Dengan interaksi yang terjadi ini manusia menciptakan budaya lusan.(Haryanto : 2012)

Kesimpulan utama yang perlu diambil dari substansi teori interaksionalisme simbolik adalah kehidupan bermasyarakat terbentuk melalui proses interaksi dan komunikasi atara individu dan kelompok dengan menggunakan simbol-simbol yang dipahami maknanya melalui proses beajar. Masyarakat Jawa khususnya Ponorogo telah sejak lama mengenal tentang budaya lusan. Namun hanya beberapa orang saja yang paham dan mengerti tentang lusan. Ini membuktikan bahwa lusan sebagai sebuah budaya peninggalan dari leluhur membutuhkan suatu interaksi yang secara terus-menerus. Masyarakat harus mempelajari secara bertahap tentang budaya yang telah lama mereka lakukan. Melalui interaksi simbolik 
para sesepuh desa memberikan pembeajaran secara bertahap kepada masyarakat khususnya kepada generasi penerusnya tentang hakikat ilmu weton, lusan dan bagaimana pembelajarannya. Khususnya tentang simbol-simbol yang dimunculkan oleh budaya weton, lusan itu sendiri.

Interaksi ini dilakukan guna pelestarian dari budaya weton ataupun larangan perkawinan lusan, ngalor-ngulon itu sendiri. Perlahan melalui interaksi para sesepuh desa mencoba menjelaskan tentang simbol-simbol apa saja yang dimunculkan oleh budaya weton, lusan sehingga secara tidak langsung masyarakat belajar tentang simbolisasi dari budaya. Dari proses interaksi dan pembelajaran itulah simbol tentang budaya weton, lusan dan perhitungannya dapat menjadi sebuah realitas dan nilai baru dalam masyarakat.

\section{Kesimpulan}

Dalam pembahasan penelitian tentang Strategi Negosiasi Masyarakat Muslim Pedesaan Atas Tradisi Perkawinan Lusan Peneliti menemukan kesimpulan sebagai berikut: Tradisi Pernikahan Lusan di Desa Duri Kecamatan Slahung Kabupaten Ponorog. Bahwa dalam melaksanakan pernikahan sebagian besar masyarakat tetap memegang teguh adat jawa. Hal ini sebagai konsekuensi warisan leluhur yang memang diyakini oleh masyarakat akan memberikan dampak baik dan buruk. Dalam hal pelarangan atas nikah lusan, masyarakat enggan untuk melaksanakan nikah lusan, namun sebagian masyarakat tetap ada yang berani. Selain nikah lusan, ada beberapa hal tentang adat pernikahan yang tetap dilaksanakan di desa Duri Kecamatan Slahung Kabupaten Ponorogo, diantaranya adalah perhitungan weton, Ngalor-Ngulon, Madep Ngarep.

Praktik Nikah Lusan di Desa Duri Kecamatan Slahung Kabupaten Ponorogo masih berlangsung sampai saat ini, bahkan sebagian masih menjadi pertimbangan utama masyarakat dalam menempuh prosesi perkawinan tersebut. Adapun masyarakat pada umumnya memahami larangan perkawinan Lusan dipahami larangan adat menikah antara anak nomer satu dan anak nomer tiga, dan masih banyak larangan-larangan adat tentang pernikahan yang diataranya, larangan perkawinan weton yaitu sebagai larangan adat perkawinan yang tidak sesuai weton atau hitungan Jawa yang hari akad nikahnya didasarkan pada perhitungan hari lahir seseorang dengan pasarannya. Larangan perkawinan Golan Mirah, dipahami sebagai larangan adat perkawinan karena perbedaan tempat tinggal calon mempelai yang satunya bertempat di Golan dan yang satunya bertempat di Mirah. Larangan perkawinan Ngalor Ngulon, dipahami sebagai larangan adat menikah bagi kedua calon yang arah tempat tinggalnya Ngalor Ngulon atau kearah utara- barat. Larangan perkawinan Madep Ngarep, dipahami sebagai larangan adat terhadap pelaksanaan perkawinan yang dimana rumah kedua pasangan saling berhadapan.

Strategi Negosiasi Perkawinan Lusan di Desa Duri Kecamatan Slahung Kabupaten Ponorogo.Diantara strategi dalam negosiasi perkawinan Lusan di Desa Duri adalah sebagaiberikut:

a. Tidak adanya Besanan, yaitu prosesi pernikahan dilangsungkan dirumah salah satu mempelai saja.

b. Nemu Anak dan Membuang Anak.yaitu mempelai laki-laki dibuang ke daerah rumah 
mempelai wanita dan ditemukan kembali dengan begitu ada istilah Nemu Anak.

c. Pihak mempelai laki-laki untuk melangsungkan akad nikah, berangkat dari rumah saudara atau tetangganya, dengan begitu otomatis mempelai laki-laki diakui sebagai anak yang rumahnya di tempati mempelai laki-laki untuk berangkat melangsungkan akad nikah.

\section{Daftar Pustaka}

Basri, Hasan. Keluarga Sakinah. Yogyakarta: Pustaka Pelajar, 2004.

George Ritzer dan Douglas J. Goodman, Teori Sosiologi Modren Cet.IV. Jakarta: Kencana, 2010.

Haar, Ter. Asas-Asas dan Sususan Hukum Adat. terj. Soebakti Poesponoto. Jakarta: Pradnya Pramita, 1983.

Hadikusuma, Hilman. Hukum Perkawinan Indonesia menurut perundangan, Hukum Adat, Hukum Agama. Bandung: CV. Mandar Maju, 2007.

Hamidi, Hukum Perkawinan Campuran (Eksogami) Ala Masyarakat Hukum Adat Tengger. Tangerang: t.p., 2010.

Hamidi, Jazim dan Dani Harianto, Hukum Perkawinan Campuran (Eksogami) Ala Masyarakat Hukum Adat Tengger. Malang: UB Press, 2007.

Haryanto, Sindung. Spektrum Teori Sosial Dari Klasik Hingga Post Modern. Yoyakarta: ARRUZZ MEDIA, 2012.

Huda, Miftahul. Membangun Model Bernegoisasi dalam Tradisi Laragan-larangan Perkawinan Jawa. Ponorogo: IAIN Ponorogo Press, 2017.

Mulyana, Dedi. Metodologi Penelitian Kualitatif . Bandung: Rosdakarya, 2002.

Purwadi, Upacara Tradisional Jawa, Mengali Untaian Kearifan Lokal. Yogyakarta: Pustaka Pelajar, 2005.

Trianto dan Titik Triwulan Tutik, Perkawinan Adat Wologoro Suku Tengger. Jakarta: Prestasi Pustaka, 2005.

Upe, Ambo. Tradisi Aliran Dalam Sosiologi Dari Filodofi Positivistik Ke Post Positivistik. Jakarta: Rajagrafindo Persada, 2010.

Wirawan, Ida Bagus. Teori-Teori Sosial Dalam Tiga Paradigma (Fakta sosial, Definisi sosial, perilaku sosial). Jakarta: Kencana, 2014. 